JPE (Jurnal Pendidikan Edutama) Vol. 6 No. 2 Juli 2019

P-ISSN : 2339-2258 (Print) E-ISSN: 2548-821X (Online)

http://ejurnal.ikippgribojonegoro.ac.id/index.php/JPE

\title{
PENGEMBANGAN PERANGKAT PEMBELAJARAN MATEMATIKA DENGAN MODEL PENEMUAN TERBIMBING (DISCOVERY LEARNING) PADA MATERI TRIGONOMETRI
}

\author{
Endang Sri Wigati \\ Jurusan MIPA, SMAN 1 Bojonegoro \\ Email: endangsriwigati@yahoo.com
}

\begin{abstract}
In teacher centered learning process, students only listen and receive what the teacher teaches, so that students become pasive because students are not invited to be directly involved in learning, this is contrary to the 2013 curriculum, that is centered on students. One of alternative to change that learning is discovery learning model. The purpose of this research is to produce a good learning tools and the effectiveness of appropriate mathematics learning with a discovery learning. This research uses the Thiagarajan development model, which consists of four stages of development, that is defining, designing, developing and distributing. The tools to be developed in this research include planning study, student's paper, and learning achievement test. The research subject are students of class X MIPA 3 of SMAN 1 Bojonegoro. The results of this research is: (1) learning tools with discovery learning are good, because the resulting learning tools is a valid based on expert validation, practical and effective. Learning tools produced are planning study, student's paper, and learning achievement test. (2) Based on the criteria for achieving the effectiveness of mathematics learning with discovery learning, it can be concluded that mathematics learning with discovery learning is effective for the trigonometry material.
\end{abstract}

Keyword: Discovery Learning, Trigonometry

\begin{abstract}
Abstrak
Dalam proses pembelajarannya terpusat pada guru, Peserta didik hanya mendengarkan dan menerima yang guru ajarkan, sehingga Peserta didik menjadi pasif karena Peserta didik tidak diajak terlibat langsung dalam pembelajaran, hal ini bertentangan dengan kurikulum 2013 yaitu pembelajaran berpusat pada peserta didik. Salah satu alternatif untuk mengubah pembelajaran tersebut yakni dengan model pembelajaran penemuan terbimbing. Tujuan penelitian ini adalah menghasilkan suatu perangkat pembelajaran yang baik dan efektivitas pembelajaran matematika yang tepat dengan model penemuan terbimbing. Penelitian ini menggunakan model pengembangan Thiagarajan, yang terdiri dari 4 tahap pengembangan yaitu pendefinisian, perancangan, pengembangan dan penyebaran. Perangkat yang akan dikembangkan dalam penelitian ini antara lain RPP, LAS, dan PHB. Subjek Penelitian ini adalah peserta didik kelas X MIPA 3 SMAN 1 Bojonegoro. Hasil penelitian diperoleh simpulan sebagai berikut: (1) perangkat pembelajaran dengan penemuan terbimbing yang baik, karena perangkat pembelajaran yang dihasilkan adalah perangkat pembelajaran yang valid berdasarkan validasi ahli, praktis dan efektif. Perangkat pembelajaran yang dihasilkan adalah $R P P, L A S$ dan PHB. (2) Berdasarkan kriteria pencapaian efektivitas pembelajaran matematika dengan model penemuan terbimbing, dapat disimpulkan bahwa pembelajaran matematika dengan model penemuan terbimbing efektif untuk materi rumus-rumus trigonometri

Kata kunci: Penemuan terbimbing, trigonometri
\end{abstract}




\section{PENDAHULUAN}

Dari hasil pra penelitian diperoleh bahwa kebanyakan peserta didik menganggap matematika pelajaran yang sulit sehingga hasil belajar matematika masih kurang memuaskan. Peserta didik hanya mendengarkan dan mencatat apa yang disampaikan oleh guru. Mereka masih enggan bertanya, mengemukakan pendapatnya dan kurangnya keaktifan dari peserta didik sendiri atau mungkin peserta didik jenuh dengan strategi yang dipakai oleh guru selama ini. Dari beberapa materi yang dianggap sulit salah satu diantaranya adalah materi trigonometri yang merupakan pelajaran baru di SMA karena pada jenjang SMP belum didapat. Sebagai contoh, hasil nilai matematika kelas X SMA Negeri 1 Bojonegoro selama dua tahun terakhir ini menunjukkan nilai mata pelajaran matematika yaitu dalam materi Aljabar, Trigonometri, Geometri, dan Kalkulus sebagai berikut:

Tabel 1: Hasil Nilai Matematika

\begin{tabular}{cccccc}
\hline \multirow{2}{*}{ No } & \multirow{2}{*}{ Tahun Pelajaran } & \multicolumn{5}{c}{ Nilai Rata-rata } \\
\cline { 3 - 6 } & & Aljabar & Trigonometri & Geometri & Kalkulus \\
\hline 1. & $2015-2016$ & 88 & 75 & 80 & 82 \\
\hline 2. & $2016-2017$ & 89 & 76 & 78 & 87 \\
\hline
\end{tabular}

Sumber: Arsip Nilai SMA Negeri 1 Bojonegoro

Terkait adanya perubahan dan pengembangan kurikulum dari KTSP 2006 menjadi Kurikulum 2013 sangat sesuai dengan kebutuhan peserta didik, karena dalam kurikulum 2013 terdapat perubahan dalam proses pembelajaran, diantaranya: proses pembelajaran dilaksanakan secara tidak langsung (indirect), menggunakan pendekatan saintifik/ pendekatan ilmiah dengan proses pembelajaran yang dikembangkan didasarkan atas prinsip pembelajaran peserta didik aktif yaitu pembelajaran berpusat pada peserta didik (Student Centered) melalui kegiatan yang biasa disebut $5 \mathrm{M}$ yaitu mengamati, menanya, mengumpulkan informasi, mengasosiasikan/mengolah informasi/menalar, mengomunikasikan. Dalam pembelajaran pada materi trigonometri, peneliti akan menggunakan model penemuan terbimbing (Discovery Learning) dengan pengembangan perangkat seperti yang disarankan oleh Thiagarajan, Semmel, dan Semmel (1974: 6) yang disebut model 4-D (Four D Models). Dengan model penemuan proses pembelajaran di kelas didominasi oleh peserta didik, sehingga peserta didik yang aktif, sedangkaan Suyanto dan Jihad (2013:84) menyebutkan peran guru hanya sebagai fasilitator dan guru hendaknya dapat menyediakan fasilitas dan memberikan pelayanan untuk memudahkan peserta didik dalam kegiatan proses pembelajaran, juga guru sebagai mediator.

Kriteria perangkat pembelajaran yang baik, adalah yang dapat menunjang pembelajaran sehingga tujuan yang diharapkan dalam pembelajaran dapat tercapai. Kegiatan pembelajaran yang efektif menurut Sani (2013:46) pada umumnya meliputi aspek-aspek sebagai berikut: berpusat pada peserta didik (Student Centered), interaksi edukatif antara guru dengan peserta didik, suasana demokratis, variasi metode mengajar, bahan yang sesuai dan bermanfaat, lingkungan yang kondusif dan sarana belajar yang menunjang. Menurut (Yosephine, 2014:6) perangkat pembelajaran yang baik adalah pembelajaran yang memenuhi kriteria valid, praktis, dan efektif.

Model Discovery Learning atau model penemuan terbimbing adalah proses belajar yang di dalamnya tidak disajikan suatu konsep dalam bentuk jadi (final), tetapi peserta didik dituntut untuk mengorganisasi sendiri cara belajarnya dalam menemukan konsep, guru berperan sebagai pembimbing dengan memberikan kesempatan kepada peserta didik agar bisa aktif, begitu juga 
pendapat guru harus dapat membimbing dan mengarahkan kegiatan belajar peserta didik sesuai dengan tujuan. Penggunaan model Discovery Learning, ingin mengubah kondisi belajar yang pasif menjadi aktif dan kreatif. Mengubah pembelajaran yang Teacher Oriented ke Student Oriented. Dengan model pembelajaran penemuan terbimbing, rangkaian kegiatan pembelajaran menekankan pada proses berpikir secara kritis dan analitis untuk mencari dan menemukan sendiri jawaban dari suatu masalah yang dipertanyakan,menurut Sanjaya (2013: 196). Adapun langkahlangkah/fase-fase model Penemuan Terbimbing, Kurniasari dan Sani (2014:30), menyebutkan, Langkahlangkah dalam model penemuan terbimbing adalah: (1) Menciptakan stimulus/pemberian rangsangan (Stimulation); (2) Menyiapkan pernyataan masalah/identifikasi masalah (problem statement); (3) Pengumpulan data (Data Collecting); (4) Pengolahan data (Data Processing); (5) Memverifikasi data/pembuktian (Verification), (6) Menarik kesimpulan/ generalisasi (Generalisation). Perangkat pembelajaran dalam penelitian ini yang dikembangkan adalah RPP, Lembar Aktivitas Siswa (LAS), dan Penilaian Hasil Belajar (PHB) pada materi trigonometri dengan sub materi aturan sinus dan aturan kosinus.

Berdasarkan latar belakang di atas, masalah penelitian adalah "bagaimanakah pengembangan perangkat dan efektivitas pembelajaran matematika dengan model penemuan terbimbing (Discovery Learning) pada materi trigonometri peserta didik kelas X MIPA SMA Negeri 1 Bojonegoro?" Tujuan penelitian ini adalah "Menghasilkan suatu perangkat pembelajaran yang baik dan efektivitas pembelajaran matematika yang tepat dengan model penemuan terbimbing pada materi trigonometri di kelas $\mathrm{X}$ MIPA SMA Negeri 1 Bojonegoro".

\section{METODE PENELITIAN}

Penelitian ini merupakan penelitian pengembangan (Development Research). Menurut Arifin (2009:15) jenis ini peneliti mengembangkan pola, urutan pembelajaran maupun praktik kependidikan lainnya. Penelitian ini tidak bermaksud untuk menguji teori yang ada tetapi untuk mengembangkan model-model pembelajaran maupun bahan-bahan pembelajaran mengacu pada teori-teori pembelajaran yang telah ada. Penelitian ini menggunakan model pengembangan Thiagarajan, yang terdiri dari 4 tahap pengembangan yaitu pendefinisian (Define), perancangan (Design), pengembangan (Develop) dan penyebaran (Disseminate). Perangkat yang akan dikembangkan dalam penelitian ini antara lain : (1) Rencana Pelaksanaan Pembelajaran (RPP), (2) Lembar Aktivitas Peserta didik (LAS), (3) Penilaian Hasil Belajar.

Subjek Penelitian pengembangan ini dilaksanakan di SMA Negeri 1 Bojonegoro dengan peserta didik kelas X MIPA 3 tahun pelajaran 2016/2017 yang terdiri atas 32 peserta didik. Instrumen dalam penelitian terdiri dari lembar validasi perangkat, lembar observasi (pengamatan), tes hasil belajar dan angket respon peserta didik. Instrumen pengumpul data uji coba perangkat pembelajaran, antara lain, (1) Lembar validasi perangkat pembelajaran yang terdiri dari; lembar validasi RPP, lembar validasi LAS, dan lembar validasi PHB, (2) Lembar observasi (pengamatan) digunakan untuk memperoleh informasi yang berkaitan dengan kegiatan mengajar belajar selama uji coba, yakni terdiri dari: Lembar observasi kemampuan guru mengelola pembelajaran, Lembar observasi aktivitas peserta didik, Angket respon peserta didik, Penilaian Hasil Belajar, Validitas butir, Sensitivitas butir, Reliabilitas butir.

Prosedur Pengembangan Perangkat Pembelajaran yang disusun dalam penelitian ini mengacu pada jenis 
pengembangan model 4-D (Four D model) yang terdiri dari 4 tahap yang telah dimodifikasi menjadi 3-D, yaitu pendefinisian (Define), perancangan (Design) dan pengembangan (Develop). Tahap Pendefinisian, tahap ini bertujuan untuk mempelajari, menetapkan dan mendefinisikan segala yang diperlukan dalam pembelajaran. Pada tahap ini terdiri atas lima langkah kegiatan, yaitu (1) analisis awal-akhir, (2) analisis peserta didik, (3) analisis materi/konsep, (4) analisis tugas, dan (5) spesifikasi tujuan pembelajaran. Tahap Perancangan,tahap ini dilakukan bertujuan untuk merancang perangkat pembelajaran sehingga diperoleh yang terdiri dari empat kegiatan yaitu: (1) Penyusunan Tes, (2) Pemilihan media, (3) Pemilihan format dan (4) Perancangan awal. Tahap Pengembangan, tujuan tahap ini adalah untuk menghasilkan perangkat pembelajaran yang telah direvisi berdasarkan masukan para ahli. Dalam uji coba ini akan diperoleh hasil pengamatan terhadap aktivitas peserta didik dan kemampuan guru dalam mengelola pembelajaran, respon peserta didik dan hasil belajar peserta didik. Setelah menghasilkan perangkat pembelajaran Draf final, karena keterbatasan waktu peneliti, maka hanya diterapkan pada 1 kelas yang diuji coba.

Teknik analisa data yang digunakan dalam penelitian ini analisis statistik diskriptif, data yang di analisis antara lain: (1) Analisis data validasi ahli, (2) Analisis data observasi (pengamatan) pengelolaan pembelajaran, (3) Analisis data aktivitas peserta didik. Penentuan kesesuaian aktivitas peserta didik berdasarkan pada Kriteria waktu ideal aktivitas peserta didik dalam pembelajaran pada tabel berikut.

Tabel 2: Kesesuaian aktivitas peserta didik

\begin{tabular}{|c|c|c|}
\hline \multirow{2}{*}{$\begin{array}{c}\text { Aspek Pengamatan Aktivitas Peserta } \\
\text { didik }\end{array}$} & \multicolumn{2}{|c|}{ Prosentase Kesesuaian $(\mathrm{P})$} \\
\hline & Waktu Ideal (\%) & Toleransi $10 \%$ \\
\hline $\begin{array}{l}\text { Mendengarkan/memperhatikan penjelasan } \\
\text { guru/teman. }\end{array}$ & $10 \%$ & $9 \% \leq \mathrm{P} \leq 11 \%$ \\
\hline $\begin{array}{l}\text { Menyelesaikan LAS / menulis yang } \\
\text { relevan dengan kegiatan pembelajaran. }\end{array}$ & $51 \%$ & $44,9 \% \leq \mathrm{P} \leq 56,1 \%$ \\
\hline $\begin{array}{l}\text { Mendengar / memperhatikan /menjawab } \\
\text { pertanyaan guru. }\end{array}$ & $10 \%$ & $9 \% \leq \mathrm{P} \leq 11 \%$ \\
\hline $\begin{array}{l}\text { Bertanya/menyampaikan pendapat/ ide } \\
\text { kepada guru atau teman. }\end{array}$ & $15 \%$ & $13,5 \% \leq \mathrm{P} \leq 16,5 \%$ \\
\hline $\begin{array}{l}\text { Menarik kesimpulan suatu konsep atau } \\
\text { prosedur. }\end{array}$ & $10 \%$ & $9 \% \leq \mathrm{P} \leq 11 \%$ \\
\hline $\begin{array}{l}\text { Perilaku yang tidak relevan dengan } \\
\text { kegiatan pembelajaran. }\end{array}$ & $4 \%$ & $3,6 \% \leq \mathrm{P} \leq 4,4 \%$ \\
\hline $\begin{array}{l}\text { Aktivitas peserta didik dikatakan } \\
\text { baik/efektif bila waktu yang digunakan } \\
\text { untuk melakukan setiap kategori } \\
\text { aktivitas sesuai dengan alokasi waktu } \\
\text { yang termuat dalam RPP dengan } \\
\text { toleransi } 10 \% \text { dari waktu total dari } \\
\text { keseluruhan waktu yang digunakan, (4) } \\
\text { Analisis data hasil belajar, diperoleh dari } \\
\text { tes hasil belajar yaitu pretest dan }\end{array}$ & $\begin{array}{l}\text { posttest, sela } \\
\text { melihat vali } \\
\text { reliabilitas. Se } \\
\text { itu diuraikan s } \\
\text { (a) Validitas } \\
\text { menentukan } \\
\text { dengan men } \\
\text { diperoleh pad } \\
\text { total. Rumus } \\
\text { rumus korelas }\end{array}$ & $\begin{array}{l}\text { nya dianalisis untuk } \\
\text { s, sensitivitas dan } \\
\text { a ringkas tiga analisis } \\
\text { gai berikut, } \\
\text { s, digunakan untuk } \\
\text { litas suatu tes adalah } \\
\text { relasikan skor yang } \\
\text { tiap butir dengan skor } \\
\text { ng digunakan adalah } \\
\text { oduct moment, yaitu: }\end{array}$ \\
\hline
\end{tabular}




$$
\mathrm{r}_{\mathrm{xy}}=\frac{N \sum X Y-\left(\sum X\right)\left(\sum Y\right)}{\sqrt{\left(N \sum X^{2}-\left(\sum X\right)^{2}\right)\left(N \sum Y^{2}-\left(\sum Y\right)^{2}\right)}}
$$

(Arikunto, 2013:87)

Dalam penelitian ini butir tes dikatakan valid jika mempunyai validitas cukup, tinggi, atau sangat tinggi sedangkan butir-butir tes yang memiliki validitas rendah dan sangat rendah akan direvisi.

(b) Reliabilitas tes, suatu tes disebut reliabel jika tes itu memberi hasil yang tetap (konsisten) walaupun dilakukan oleh orang lain, pada waktu dan tempat yang berbeda (Arikunto,2013; 74). Untuk menentukan koefisien reliabilitas suatu tes bentuk uraian dapat ditaksir dengan menggunakan rumus Alpha sebagai berikut.

$$
r_{11}(\alpha)=\left(\frac{n}{(n-1)}\right)\left(1-\frac{\sum \sigma_{i}^{2}}{\sigma_{t}^{2}}\right)
$$

(Arikunto, 2013:122)

(c) Sensitivitas tes dihitung untuk mengetahui efek (pengaruh) dari suatu pembelajaran. Indeks sensitivitas dari suatu butir soal pada dasarnya merupakan ukuran seberapa baik butir soal itu membedakan antara peserta didik yang telah menerima dengan peserta didik yang belum menerima pembelajaran.Untuk menghitung sensitivitas butir soal ini digunakan rumus sebagai berikut (Grounlund, 1982: 106).

$$
S=\frac{\sum \mathrm{S}_{\mathrm{es}}-\sum S_{e b}}{N\left(S k o r_{\max }-S k o r_{\min }\right)}
$$

Menurut Aiken (dalam Trianto, 2009: 242). Butir soal dikatakan baik apabila sensitivitas berada antar 0 dan 1 , kriteria yang dipakai untuk menyatakan bahwa butir soal peka terhadap pembelajaran jika $S \geq 0,30$. Jika $S<0,30$ maka butir soal akan direvisi. Dari beberapa kriteria diatas, secara secara keseluruhan perangkat pembelajaran dikatakan baik apabila memenuhi kriteria sebagai berikut: kemampuan guru mengelola pembelajaran dalam kategori efektif, aktivitas peserta didik selama pembelajaran dalam kategori efektif, respon peserta didik terhadap perangkat dan pelaksanaan pembelajaran positif, serta tes hasil belajar peserta didik dalam kategori sensitive (peka), valid dan reliabel.

(5) Analisis data respon peserta didik, diperoleh melalui angket respon peserta didik dianalisis dengan menggunakan statistik deskriptif dalam bentuk prosentase. Prosentase dari setiap respon peserta didik dihitung dengan rumus:

\section{Jumlah respon positif peserta $\frac{\text { didik tiap aspek yang muncul }}{\text { Jumlah seluruh peserta didik }} \times 100 \%$}

Respon peserta didik dikatakan positif jika jawaban peserta didik terhadap pernyataan positif untuk setiap aspek yang direspon pada setiap komponen pembelajaran diperoleh prosentase $\geq$ $80 \%$. Hasil analisis data tentang respon peserta didik tersebut akan digunakan untuk merevisi perangkat pembelajaran.

\section{HASIL DAN PEMBAHASAN}

Hasil dari validasi oleh para validator terhadap Rencana Pelaksanaan Pembelajaran (RPP), Lembar Aktivitas Peserta didik (LAS) dan Penilaian Hasil Belajar (PHB). Setelah dilakukan analisis oleh Ahli didapat bahwa sebanyak 28 komponen RPP Pertama dan kedua mendapat nilai di atas 2,5, sedangkan 8 komponen yang lain mendapat nilai rata-rata dari RPP Pertama dan kedua sebanyak 2,5 sehingga dikategorikan Baik. Sehingga sesuai dengan peringkat penilaian, maka hasil validasi RPP diatas, dan setelah di rata-rata nilainya dikatagorikan amat baik.

Hasil Validasi untuk lembar aktivitas peserta didik diperoleh sebanyak 10 aspek mendapat nilai ratarata 5 dengan kategori sangat baik, dan 7 aspek yang lain mendapat nilai rata-rata lebih dari 4,5 dengan kategori baik. Tidak jauh berbeda dari penilaian 
analisis untuk RPP, penilaian LAS juga menghasilkan hasil yang Sangat baik.

Validasi ahli yang terakhir dilakukan pada Penilaian hasil belajar (PHB). Penilaian Validator terhadap Penilaian Hasil Belajar adalah Validasi Isi Valid, Bahasa dan Penulisan Sangat mudah difahami, Rekomendasinya dapat digunakan tanpa revisi.

Berdasarkan data di atas, secara umum hasil validasi para validator terhadap perangkat pembelajaran dapat disimpulkan sebagai berikut: (1) Rencana Pelaksanaan Pembelajaran (RPP) mempunyai kategori amat baik dan dapat digunakan dengan sedikit revisi. (2) Lembar Aktivitas Peserta didik (LAS) mempunyai kategori baik dan dapat digunakan dengan sedikit revisi. (3) Penilaian Hasil Belajar (PHB) dinyatakan valid atau cukup valid, bahasa dan penulisan sangat dapat dipahami atau dipahami dan dapat digunakan dengan sedikit revisi.

Data yang dikumpulkan dalam pelaksanaan uji coba yaitu: Data kemampuan guru mengelola pembelajaran, data aktivitas peserta didik, data respon peserta didik dan data hasil belajar. (1) Data kemampuan guru mengelola pembelajaran diperoleh hasil sebagai berikut: pada aspek pendahuluan nilai rata-rata yang dicapai pada pertemuan Pertama adalah 4,75 dan pertemuan kedua sebesar 4,5. Pada kegiatan inti nilai rata-rata yang diperoleh pada pertemuan pertama adalah 4,57, dan pertemuan kedua juga 4,57. Pada kegiatan penutup nilai ratarata yang diperoleh pada pertemuan pertama adalah 4,46 dan pada pertemuan kedua sebesar 4,39. Hasil analisis data ini menunjukkan bahwa rata-rata skor kemampuan guru mengelola pembelajaran untuk RPP 1 dan RPP 2 mempunyai kriteria baik.

(2) Data aktivitas peserta didik dalam pembelajaran yang diperoleh adalah sebagai berikut: pada aspek mendengarkan penjelasan guru pada pertemuan Pertama dan kedua persentase aktivitas peserta didik adalah $9,85 \%$ untuk rentang ideal $9 \%-11 \%$, pada aspek kedua yaitu menyelesaikan LAS Persentase aktivitas peserta didik adalah 53,4 \% dari rentang 44,9\% $56,1 \%$. Pada aspek ketiga menjawab pertanyaan guru aktivitas peserta didik sebanyak 9,35\% dari rentang nilai 9\%$11 \%$. Pada aspek keempat menyampaikan pendapat aktivitas peserta didik sebanyak $14,7 \%$ dari rentang nilai $13,5 \%-16,5 \%$. Pada aspek kelima menarik kesimpulan sebanyak 9,8\% dari rentang nilai 9\%-11\% peserta didik telah aktif melakukan kegiatan. Pada aspek terakhir yakni prilaku peserta didik di dalam kelas, aktifitas peserta didik hanya mencapai 2,25\% dari rentang 3,6\%-4,4\%. Ditinjau dari aspek aktivitas peserta didik maka memenuhi kriteria efektif. (3) Data Respon peserta didik. Hasil angket respon peserta didik disajikan adalah sebagai berikut: $100 \%$ peserta didik merasa bersemangat saat guru memberikan LAS untuk diselesaikan, 93,75\% peserta didik dapat memahami petunjuk atau langkah-langkah dalam menggunakan LAS. 90,63\% peserta didik merasa tertarik pada penampilan yang ada pada LAS. 93,75 \% peserta didik mengacu bimbingan guru membantu mereka dalam menyelesaikan masalah dalam LAS. 93,75 \% peserta didik juga mengatakan mereka memahami materi dan konsep melalui diskusi kelompok. 90,63\% peserta didik mendapat bantuan dalam penguasaan konsep melalui LAS. $100 \%$ peserta didik merasa jelas dengan verivikasi yang dilakukan pada setiap hasil diskusi kelompok, meskipun mereka baru mengalami pembelajaran dengan metode penemuan terbimbing. Sebanyak 90,63\% peserta didik merasa senang dan lebih berminat belajar dengan menggunakan metode penemuan terbimbing. Respon peserta didik dikatakan positif apabila prosentase setiap aspek lebih dari atau sama dengan $80 \%$, maka dapat disimpulkan: Respon peserta didik tentang komponen mengajar positif dan peserta didik merasa bersemangat untuk mengikuti pelajaran selanjutnya. 
(3)Data Hasil Belajar, data hasil belajar dianalisis untuk melihat validitas, sensitivitas dan reliabilitas instrumen tes hasil belajar. Hasil perhitungan validitas setiap butir tes disajikan pada Tabel berikut:

Tabel 3: Validitas Hasil Belajar

\begin{tabular}{ccccccccc}
\hline No soal & 1 & 2 & 3 & 4 & 5 & 6 & 7 & 8 \\
\hline $\mathrm{r}_{\mathrm{xy}}$ & 0.553 & 0.805 & 0.792 & 0.903 & 0.447 & 0.870 & 0.743 & 0.748 \\
\hline Valid & Cukup & $\begin{array}{c}\text { Sangat } \\
\text { Tinggi }\end{array}$ & Tinggi & $\begin{array}{c}\text { Sangat } \\
\text { Tinggi }\end{array}$ & Cukup & $\begin{array}{c}\text { Sangat } \\
\text { Tinggi }\end{array}$ & Tinggi & Tinggi \\
\hline
\end{tabular}

Berdasarkan kriteria kelayakan butir tes,maka setiap butir tes dikategorikan valid dan layak digunakan dalam penelitian.selanjutnya berdasarkan hasil perhitungan reliabilitas tes (Tahap Uji Coba) diperoleh koefisien reliabilitas tes
0,852 . Ini berarti butir tes memenuhi kriteria reliabel. Setelah hasil belajar dinyatakan valid dan reliable selanjutkan dilakukan analisis untuk mengetahi taraf sensitivitas hasil belajar. Hasil perhitungan sensitivitas setiap butir soal dalam Tabel berikut:

Tabel 4: Perhitungan Sensitivitas Hasil Belajar

\begin{tabular}{ccccccccc}
\hline No soal & 1 & 2 & 3 & 4 & 5 & 6 & 7 & 8 \\
\hline S & 0.59 & 0.64 & 0.61 & 0.69 & 0.99 & 0.84 & 0.84 & 0.79 \\
\hline Sensitivitas & Peka & Peka & Peka & Peka & Peka & Peka & Peka & Peka \\
\hline
\end{tabular}

Berdasarkan kriteria, sensitivitasnya lebih besar atau sama dengan 0,30 . Hal ini berarti semua butir tes memenuhi kriteria sensitif sehingga layak digunakan dalam penelitian.

Setelah melakukan analisis hasil belajar peneliti juga mengemukakan hasil ketuntasan belajar peserta didik. Nilai rata-rata yang diperoleh adalah 81,53 , dengan nilai tertiggi 100 dan nilai terendah 42 untuk jumlah peserta didik yang tuntas 26 orang dan yang tidak tuntas 6 orang, dan Persentase ketuntasan sebesar $81,25 \%$.

\section{SIMPULAN}

Berdasarkan hasil penelitian diperoleh simpulan sebagai berikut: (1) Pengembangan perangkat pembelajaran pada penelitian ini menggunakan model 4-D yang telah dimodifikasi, dihasilkan perangkat pembelajaran dengan model penemuan terbimbing (Discovery Learning) yang baik, karena perangkat pembelajaran yang dihasilkan adalah perangkat pembelajaran yang valid berdasarkan validasi ahli, praktis dan efektif. Perangkat pembelajaran yang dihasilkan adalah Rencana Pelaksanaan Pembelajaran (RPP), Lembar Aktifitas Peserta didik (LAS) dan Penilaian Hasil Belajar (PHB). (2) Berdasarkan kriteria pencapaian efektivitas pembelajaran matematika dengan model penemuan terbimbing, dapat disimpulkan bahwa pembelajaran matematika dengan model penemuan terbimbing efektif untuk materi rumus-rumus segitiga yaitu sub

materi aturan sinus dan aturan kosinus, karena telah memenuhi kriteria dari hasil uji coba lapangan menunjukkan kemampuan guru mengelola pembelajaran efektif, aktivitas peserta didik efektif, respon peserta didik terhadap pembelajaran positif, dan tes hasil belajar memenuhi kriteria baik karena ketuntasan belajar 81,25\% diatas batas minimum syarat aspek ketercapaian tingkat ketuntasan belajar yaitu minimal $80 \%$, dan dalam penelitian dalam penguasaan bahan ajar peserta didik mencapai 81,53 sudah 
diatas syarat ketentuan penguasaan bahan ajar minimal $75 \%$.

SARAN.

Berdasarkan hasil penelitian ini, beberapa saran sebagai berikut: (1) Bagi guru yang berminat, dapat menggunakan beberapa perangkat pembelajaran yang sudah memenuhi kriterianya. (2) Menggunakan perangkat pembelajaran model penemuan terbimbing yang dihasilkan sebagai salah satu perangkat yang digunakan dalam pembelajaran matematika khususnya untuk materi aturan sinus dan aturan kosinus. (3) Agar mendapatkan hasil yang optimal disarankan kepada peneliti lain untuk meminimalisasi kelemahan pada penelitian yang sudah dilakukan. (4) Bagi peneliti lain yang berminat terhadap penelitian sejenis ini, maka hasil penelitian ini dapat dijadikan masukan bagi penelitiannya.
DAFTAR PUSTAKA

Arifin, Z. (2009). Metodologi Penelitian Pendidikan. Surabaya: Lentera Cendekia.

Arikunto, S. (ed.) (2013). Dasar-Dasar Evaluasi Pendidikan. Jakarta: Bumi Aksara.

Kurniasih, I., dan Sani, B. (2014). Implementasi Kurikulum 2013 Konsep dan penerapan. Surabaya: Kata Pena.

Sanjaya, W. H. (2013). Strategi Pembelajaran. Jakarta: Kencana.

Sani, A. R. (2013). Inovasi Pembelajaran. Jakarta: Bumi Aksara.

Suyanto dan Jihad, A (2013). Menjadi Guru Profesional. Jakarta: Erlangga

Thiagarajan, Sivasailam, Semmel, S., Semmel, Melvyn L. (1974). Instroductional Development for Training Teachers of Exceptional Children, A Source Book, Blomington: Center of Inovation on Teaching the Handicapped. Minnepolis: Indiana University 